ARTIKEL

\title{
THE ROLE OF INTEGRATED SERVICE POST CADRES IN THE JAVANESE COUNTRYSIDE
}

\author{
Cucu Sugyati, Diah Fatma Sjoraida \\ Universitas Padjadjaran, Bandung, Indonesia \\ susantig@yahoo.co.id
}

\begin{abstract}
This study seeks to make a deep, systematic analysis of the urgency of implementing elements in the implementation of public health policies, especially in the field of mother and child in West Java, Indonesia. This study is important in order to evaluate whether the government services on maternal and child health is sufficient or not. With descriptive-qualitative method this study presents a discussion of how the implementers interact with the community implementing public bealth programs in West Java province so that their presence is indispensable. With theories of implementation of policies and health promotion, the data was obtained and it showed that (a) the unity of the coordination and uniformity of information services, and a network of cooperation in public health institutions, in the Provincial Government of West Java have been performed well; (b) in implementing their obligations the implementers are highly motivated for the services of public health has become a major function in the duties and functions of the health department. However, the lack of health care workers who directly addressing maternal and child health were perceived by the public so well that this study recommend the convening of additional health workers in the community.
\end{abstract}

Keyword: Public Health Policy, West Java, Media, Structure of Policy

\begin{abstract}
Abstrak
Penelitian ini berusaha untuk membuat analisis yang mendalam dan sistematis tentang urgensi elemen pelaksana dalam pelaksanaan kebijakan kesehatan masyarakat, khususnya di bidang ibu dan anak di Jawa Barat, Indonesia. Penelitian ini penting untuk mengevaluasi apakah layanan pemerintah pada kesehatan ibu dan anak sudah cukup atau tidak. Dengan metode deskriptif-kualitatif, penelitian ini menyajikan diskusi tentang bagaimana pelaksana berinteraksi dengan masyarakat yang menerapkan program kesehatan masyarakat di Provinsi Jawa Barat sehingga kehadiran mereka sangat diperlukan. Dengan teori implementasi kebijakan dan promosi kesehatan, data diperoleh dan menunjukkan bahwa (a) kesatuan koordinasi dan keseragaman layanan informasi, dan jaringan kerja sama di lembaga kesehatan masyarakat, di Pemerintah Provinsi Jawa Barat telah dilakukan dengan baik; (b) dalam melaksanakan kewajiban mereka para pelaksana sangat termotivasi untuk layanan kesehatan masyarakat telah menjadi fungsi utama dalam tugas dan fungsi departemen kesehatan. Namun, kurangnya petugas layanan kesehatan yang secara langsung menangani kesehatan ibu dan anak dirasakan oleh masyarakat dengan baik sehingga penelitian ini merekomendasikan diadakannya petugas kesehatan tambahan di masyarakat.
\end{abstract}

Kata Kunci: Kebijakan Kesehatan Masyarakat, Jawa Barat, Media, Struktur Kebijakan

\section{A. Introduction}

Temali: Jurnal Pembangunan Sosial, Volume 1 Nomor 2 Tahun 2018 
ARTIKEL

Health is one of the basic needs for the life of individuals, families and communities which is achieved through a variety of efforts. From the standpoint of Human Rights (HR), the Government of Indonesia's commitment to the global community can be seen as part of efforts to meet the obligations in realizing the right to health, especially maternal health. Maternal health problems, especially those related to maternal mortality and morbidity (the irregularities), has recognized the community as a human rights issue. It is associated with several human rights, especially the right to a standard of health, is the highest. The world community is already committed that this right should be protected. These rights are protected by the treaties of international human rights, enshrined in the Convention on the Elimination of All Forms of Discrimination Against Women (CEDAW) and the International Covenant on Economic, Social and Cultural Rights (ICESCR) (Sugyati, Sjoraida, Anwar, 2017).

In line with Article 2 of the International Covenant on Economic, Social and Cultural Rights (ICESCR), it is the duty explicitly for a state to take definite action in realizing the rights of economic, social and cultural, which means that the state should not back down from the level of achievement have been implemented earlier. Another important government liability is "the maximum utilization of resources that exist": The government must show that such activities utilizing existing resources optimally to achieve the right to health. Referring to the principle of government as a duty bearer who holds the obligation to respect, protect and facilitate the realization of the rights of the mother's health, the budget analysis of maternal health must be addressed in the assessment activities of the government to (1) to take appropriate action towards progress in achieving the right to health of the mother, and (2) Utilization of existing resources optimally. Government budget allocations in the areas of maternal health, especially to realize the government's promise on the MDGs in the UN summit in 2010, must show that such activities earlier.

It is known that health is achieved through a variety ways. A variety of efforts to be healthy held by various parties is a series of health development. In Indonesia, the development of the health sector is the manifestation of Article 28 paragraph (1) of the Constitution of 1945 which states that everyone has the right to health, and 
ARTIKEL

Article 34 paragraph (3) states that the state is responsible for the provision of health care facilities and facilities for decent public services.

In order to implement health development effectively it is clearly needed the support of health sector resources as mandated by Article 1 of Law No. 36 of 2009 on Health (Presiden, 2009). The resources in the health sector are any forms of funding, personnel, medical supplies, pharmaceutical supplies and medical devices and health care facilities and technologies used to conduct health efforts undertaken by the Government, local government, and / or the community. Such support resources of the health sector are needed in local governance. The purpose of regional governance as stipulated in Law No. 23 Year 2014 on Regional Government is public welfare (Indonesia, R., \& Nomor, U. U. (23). Tahun 2014).

The decrease or low degree of health, among others, are the phenomena of an unhealthy lifestyle, lack of awareness to maintain hygiene and environmental health, declining health of individuals and families, malnutrition, and the outbreaks of infectious diseases. The impact of the low degree of health is certainly not confined to the lives of individuals and families. Social life can be affected from the declining in health status. Therefore, we need a variety of approaches to increase developing efforts of health. Objective health efforts as stated by Article 3 of Law No. 36 Year 2009 on Health is raising the awareness, willingness and ability of healthy life for everyone in order to realize optimal degree of public health through disease prevention and health maintenance.

To improve the community's health status, among others, is achieved by organizing public health services. To organize effective public health services, the Government had issued Regulation of the Minister of Health No. 741 / Menkes / Per / VII / 2008 on Minimum Service Standards for Health. Article 2 (2) The Minister of Health states: "The type of service of the health sector includes: primary health care (visiting pregnant women, obstetric complications, delivery assistance, post-partum, neonatal, child immunization, toddlers, complementary feeding, children malnutrition, health of students, Family Planning, poor public services), health care referrals (poor patients and the emergency level 1), epidemiology and prevention of outbreaks, as well as health promotion and community development)." (Kesehatan, 2008). 
ARTIKEL

Although the organizers of health services also carried out by private parties, in order to make basic health services that include visits of pregnant women, obstetric complications, delivery assistance, post-partum, neonatal, child immunization, toddlers, complementary feeding, children malnutrition, medical students, Family Planning participants, and poor public services to be effective, local governments need to expand the provision of health care infrastructure. To that end, the Government established the Regional General Hospital (RSUD) and Community Health Centers (CHC, Puskesmas) as well as motivating people to organize Integrated Service posts (Posyandu) on the level of neighborhoods (RT and RW). Posyandu functions are carried out by the Family Guidance Group (PKK) or the groups of women forming community participation in health efforts.

Public health efforts organized by the Regional Government are the implementation of Article 12 paragraph (1) of Law Number 23 Year 2014 About the Regional Government. The verse states that it is mandatory for the government to serve basic services such as health services. Related to this policy, the Government has issued Government Regulation No. 65 Year 2005 on the Guidelines for the Preparation of Minimum Service Standards, Government Regulation Number 6 Year 2007 on Technical Guidelines for Preparation and Determination of Minimum Service Standards, and in particular, the minimum service standards in hospitals governed by Decree Minister of Health No. 129 / Menkes / SK / II / 2008 on Minimum Service Standards Hospital. In this context, the quality of basic health services could be crucial in supporting the realization of public welfare (Kesehatan, 2008).

In efforts to satisfy the community with their services, the government made a State Owned Enterprise (BUMN), namely the Social Security Agency (BPJS). However, its existence, structure, services and operations are still need to be socialized. This is where the parties concerned with public health either the government health departments or the BPJS should disseminate the new structure of services. The most massive of dissemination to the public is certainly the mass media. And it also is a responsible burden for the local implementers of public health policies (Sugyati, 2018). 


\section{B. Theoretical Review}

In line with the mandate of Article $28 \mathrm{H}$ paragraph (1) of the Constitution of the Republic of Indonesia Year 1945 it has been affirmed that every person has the right to obtain medical care, and in Article 34 paragraph (3) it is declared that the state is responsible for the provision of health care facilities and public service facilities worthy.

Referring to the explanation of the article, the health authority is included as a health service provided by the government, as well as the West Java provincial government for the level of the District / City and Sub-District / Village. Furthermore, the implementation of health services is guided by the Regulation of the Minister of Health No. 741 / Menkes / Per / VII / 2008 on Minimum Service Standards for Health in the District / City.

The function of conducting health services should reach all targets, primarily health services to the poor community. Thus the West Java Provincial Government established the Community Health Centers as the spearhead of public health services. The function of this health center is also closely related to the implementation of the functions of Integrated Service posts (Posyandu) carried out by the groups of women working for the communities of the RT, RW, and the village.

Public health efforts organized by the Regional Government are the implementation of Article 11 (4) of Law No. 32 of 2004 which states that "The implementation of mandatory affairs is guided by the minimum service standards implemented gradually and is set by the Government". To that end, the Government issued Government Regulation No. 65 Year 2005 on Guidelines for the Preparation of Minimum Service Standards, Government Regulation Number 6 Year 2007 on Technical Guidelines for Preparation and Determination of Minimum Service Standards, and in particular, the minimum service standards in hospitals regulated by the Ministerial Decree No. : 129 / Menkes / SK / II / 2008 on Minimum Service Standards Hospital. In this context, the implementation of the policy of minimum service standards is important in determining the quality of health services (Anwar, Rusmana, and Rahman, 2018).

To that end, policies and health services need to be directed and optimized to increase public knowledge of the importance of health. Meanwhile, optimal health 
ARTIKEL

care can only be held if the resources of health care can be met. Health resources are certainly not only the provision of health alone, but they also include other health resources such as budget provision of health services, provision of facilities and infrastructure of health services and the use of health technology which is increasingly more and more sophisticated and complete. On the one hand, the provision of health care resources can be met by health care institutions organized by business parties. However, the costs of obtaining health care organized by the private sector are considered much more expensive compared to that of health care held by government agencies.

According to Azwar (1996), there are the terms of the basic health services that must be met in order to be regarded as good health services, namely:

1. Available and sustainable.

2. Acceptable and reasonable.

3. Easily accessible, especially from the point of location.

4. Easy to reach, mainly from the cost perspective.

5. Qualified.

In the context of health services utilization there are interactions between the consumers and the service providers. Some of the factors that influence the utilization of health services are related to socio-cultural factors, organizational factors, recipients of services and service provider's factors.

Socio-cultural factors consist of technology and social values that exist in the society. The advances in technology may be able to improve the utilization of health services such as a heart transplant, a kidney, the invention of artificial organs, as well as advances in the field of radiology (Dever, 1984). In this context, there should be considerations on local wisdom including norms, values and beliefs in the society. This will affect someone in the act included in an effort to utilize health services.

Furthermore, factors relating to the organization are the structures and the processes that give the policy to the organization of health services and the surrounding environment that affect the health care process. These factors are the availability of resources, geographic access, social access as well as characteristics of the structure and process of care (Dever, 1984). 
ARTIKEL

Meanwhile, Gordon (1986: 20) said that implementation of the policy with regard to a variety of activities aimed at the realization of the program. In this case, the administrator set up ways to organize, interpret and implement policies that have been selected. To organize means managing resource units, and methods for implementing the program. Interpretation with respect to translate the language or terminology program into plans and guidelines that are acceptable and feasible, while applying means using instruments, working or providing routine services, make those payments. Or in other words the implementation stage of realizing the goals of the program. In this case to note is the preparation of implementation, which is to think and calculate carefully the various possibilities of success and failure, including barriers and opportunities that exist and the ability of the organization entrusted with the task to implement the program. Thus, according to Pressman and Wildavsky (1973), M. Howlett and Ramesh (1995) and Gordon (1986), the implementation of public policy has the prerequisites, namely:

1. Implementation of public policy contains something / some purpose or purposes;

2. In the public policy there is something that underlies the emergence of the idea of the policy;

3. The public policy contains a series of activities aimed at the realization of the program;

4. In the realization of the program, it is the task of government administrator (bureaucracy) to interpret, organize and implement the policy;

5. Implementing a policy requires a wide range of instruments and resources.

Based on the opinion as cited above, it can be concluded that the implementation of a policy administration tool, where various actors, organizations, procedures and techniques work together running policies in order to achieve the desired effects or purposes. The successful achievement of policy objectives depends on the actors participating in the implementation of the policy. Therefore, Michael Howlett and M. Ramesh (1995), Charles O. Jones (1984), and Gordon (1986) explains that the implementation of the policy can be seen as a process of strategic interaction that exists of cooperation between a large number of actors involved in the implementation of policies to achieve policy mandates. The participation of a 
group of such individuals in the implementation of the policy may have some form and in collaboration with government agencies.

Many people think that the implementation of the policy is only the application of what has been decided by the legislatures or the decision makers so that it is less influential. In fact, not all policies can be implemented properly. A policy that is brilliant even if implemented improperly could be doomed to failure in achieving objectives. Therefore, the study of policy implementation is in regard to the achievement of the goals and objectives of the decision makers or policy. A similar opinion was expressed by Udoji (1981: 15), that "the execution of the policies is as important if not more important than policy-making. Policies will remain dreams or blue prints file jackets unless they are implemented". The policies would just be a dream or a good plan that is neatly stored in the archive if it is not implemented. Such Udoji's opinion Udoji hints that the implementation of policies determines the success and failure of a policy.

Based on the various opinions that have been described above, the implementation of the policy includes actions by various actors, particularly the bureaucrats that are intended to make the program run. Furthermore, it can be said that the implementation of the first policy covers a range of implementing agencies tasked by the Law with responsibility in running the program, so that they must obtain the resources needed for the smooth administration. The sources in question include personnel, equipment, plots of land, raw materials and funds. Second, the implementing agencies to develop the language statutes into concrete directives, regulations and plans and program design. Third, agencies must organize their activities by creating units of the bureaucracy and routinely coping with the workload. And finally executing agencies provide benefits or restrictions to the customer or target groups as a form of real output of a program.

Thus, the implementation of the policy in principle is a process and a relationship in which the rules of the actions carried out both by individuals and officials, and government officials directed at achieving the goals set forth in policy decisions. The successful implementation of a policy depends on the ability of an organizer or actors involved / participate in the implementation of policy, by 
ARTIKEL

formulating policy objectives clearly and are able to understand, manage resources units, and set out the methods for the implementation of the program.

Executive element is the implementer of policies described (Dimock \& Dimock, 1953: 28) as: "the parties are pursuing a policy which consists of setting organizational goals and targets, analyzing and formulating organizational policies and strategies, decision-making, planning, programming, organizing, mobilizing the humans, implementing, monitoring and assessing an operation".

Parties involved fully in the implementation of public policy are the bureaucracies as described by Ripley and Franklin (1980: 27): "bureaucracies are dominant in the implementation of programs and policies and have varying degrees of importance in other stages of the policy process. In policy and program formulation and legitimation activities, bureaucratic units play a large role, although they are not dominant".

\section{Methods}

Object of this research is the the urgence of the implementers of health care of mothers and children in West Java Province. The research approach used here is based on the paradigm of qualitative research methods with deductive analysis. This research approach was chosen because that qualitative research with the method is a research approach that includes extracting the subject matter in depth (Denzin and Lincoln, 1994: 66).

The purpose of qualitative research is to understand the circumstances, events, groups, or certain social interaction (Locke, Spirduso, \& Silverman, 1987). This study can be interpreted as an investigative process in which researchers gradually make sense of a social phenomenon by differentiating, comparing, reproducing, cataloguing, and classifying the object of research (Miles \& Huberman, 1994). Marshall and Rossman (1989) say that this study involves researchers to delve into the natural setting. The researchers entered the world of the informants through continuous interactions, looking for the meanings and perspectives of the informants. 


\section{Results and Discussion}

Maternal and child health services in West Java province are apparently still not optimal. This condition would have a wide impact. The impact of not optimal quantitative health services for mothers and infants in West Java province is revealed, among others, by the data. It is unfold from the health data of West Java province which shows that in 2015 alone in West Java province there are 71805 babies were born who were referred because born with low birth weight. The number of babies suffering from malnutrition in West Java province in 2015 reached 2,979 infants or 0.30 percent of the babies born in the same year as many as 988,356 babies. Thus, maternal and child health services in West Java province, as a phenomenon of the performance of health services do health authorities in West Java Province often being criticized.

Despite the minimum service standards in the field of health has been published, but that does not mean that health development objectives as stated in Law No. 36 Year 2009 on Health can be achieved optimally. Similarly, because everyone is entitled to social security to meet the needs of basic life and enhance the dignity towards the creation of a prosperous Indonesia, equitable, and prosperous, the facilities of health should be improved. In accordance with Law No. 40 of 2004 on National Social Security System (Navigation), social security is one form of social protection to ensure that all people in order to meet the basic needs of life and decent work. Social security related to compensation and welfare programs organized by the government for all the people of Indonesia.

Referring to the issue of the quality of health services, public health efforts organized by the Regional Government is the implementation of Article 11 (4) of Law No. 32 of 2004 which states that "The implementation of affairs which is compulsory and must be guided by the minimum service standards implemented gradually and set by the Government ". To that end, the Government issued Government Regulation No. 65 Year 2005 on Guidelines for the Preparation of Minimum Service Standards, Government Regulation Number 6 Year 2007 on Technical Guidelines for Preparation and Determination of Minimum Service Standards, and in particular, the minimum service standards in hospitals regulated by the Ministerial Decree No. : 129 / Menkes / SK / II / 2008 on Minimum Service 
ARTIKEL

Standards Hospital. In this context, the implementation of the policy of minimum service standards is important in determining the quality of health services (Sugyati, 2018).

The activities are coordinated between the central and local governments to address the issue of maternal health are still an issue for the implementation of regional autonomy. Indonesia has started a massive decentralization system since 2000 after the collapse of the New Order regime in 1998. The decentralization framework itself has undergone a series of revisions. The decentralization laws in the first after the New Order regime are Law No.22 / 1999 on Regional Autonomy, the enforcement in 2000. In 2004, the government enacted Law No.32 / 2004 as a response to the impact caused by the previous law. However, in this decentralized system, the responsibility of government, including the mother's health sector is divided on the level of the national government, provinces and districts.

Health delivery system is also affected by the decentralization process in Indonesia. Since the beginning of the decentralization law in 1999, the government moved about $70 \%$ of civil servants including partial responsibility center for community services and facilities to the district level. The reforms helped move the sizable funds to local governments, but unfortunately, this transfer is not accompanied by the transfer of capacity to carry out the new responsibilities resulting in stagnant development in many areas of development, including the health sector.

The reforms of decentralization also resulted in increased availability of financial resources to local governments through decentralization transfer of funds from central to local governments. However, this has not always contributed to the increased funding for the health sector. Interestingly, the health sector in the district experienced a financial shortfall. The health sector must compete with other sectors to receive a budget allocation from the General Allocation Fund (DAU) and revenue (PAD). In some areas, the health sector received a budget allocation that is relatively lower. Shortcomings in the health sector funding also occur in areas with high fiscal capacity, which will be in a position to finance the provision of health services for the population adequately. This situation could undermine progress in health indicators over the past decade. This leads to an increasing trend of central government funding 
in the health sector directly from the Ministry of Health, which means the district government and increasing reliance on central government funding.

At the national level, the health system in Indonesia are arranged in six key areas of the program, includes the Maternal and Child Health, Health Care Fund, Human Resources, Pharmaceutical, Medical Supplies and Equipment, Information Management and Health and Community Empowerment. At the local level, Planning (Regional Planning Agency) is responsible for coordinating the development of regional policy, development planning and budgeting. District Health Office is responsible for health-related programs and projects, and to develop technical standards. The provincial health office is responsible for coordinating programs and projects in the health sector between districts, and is responsible for health problems among the districts. Through these de-concentrated tasks, the provincial health bureau also implements national health policies and programs within its jurisdiction.

In response to a variety of health sector performance outcomes among district governments as mentioned earlier, the Ministry of Health has developed minimum service standards in the field of health. The standard was developed to provide some concrete indicators that will be used to measure the performance of health authorities and local governments in the sectors of health.

Health care delivery in Indonesia arranged in a hierarchical health care system or from the bottom up. The first level is the health care delivery system in the community, involving the Community Health Center (CHC, Puskesmas); Integrated Service Posts (Posyandu), Post Maternity Village (Polindes), and village midwives. CHC is run by the government as an extension of the District Health Office provides basic health services in the districts. In order to serve remote villages that are beyond the reach of health centers, assistant health centers (Pustu) may be established under the supervision of the health center. Polindes run by nurses and midwives who are placed by the government and assisted by village health volunteers.

Integrated Service Posts (ISP, Posyandu) is the backbone of the community participation in health care. ISP was originally introduced as a component of a national program to provide basic nutrition and growth monitoring services at the community level. ISP is run entirely by volunteers trained as a health worker. That activity is one example of large-scale nutrition projects which is most successful in Indonesia, and has 
ARTIKEL

managed to provide nutrition services to 10 million children in 1984. The basic role of Posyandu then expanded in the mid 1980s to enter public activities associated with the Family Planning (FP, Keluarga Berencana) and provision of basic health services such as immunization and control of diarrheal disease with the support of health professionals.

The second health care provided by the hospital district, so it is also called Type C and D, which are served by at least four specialists. Referrals from health centers are required to access hospital services, except in emergencies. The third health care implemented by the provincial hospitals (type B and C).

Public health facilities were previously financed by the central government. Now it is funded by the region. But after decentralization, local governments have failed to allocate sufficient funds to provide basic health services. Operator health care still relies on dues paid by the public health. Dependence on the levy has resulted in increased financial barriers for the poor. It also has created perverse incentives for facilities that do not provide public health interventions, including preventive care measures, less favorable than the healing intervention. This situation has led the central government to introduce a national program such as Health Insurance for the Poor (HIP, Askeskin), which is then converted into Health Security of the Community (HSC, Jamkesmas), to provide assistance for the poor to access health services.

Nationally, in the period of 2008-2011, the number of health centers (including CHC Care) has increased from 8548 units in 2008 to 9321 units in 2011. In the period, the ratio of health center to 100,000 population is in the range of 2.06 to 15.99 per 100,000 population, this means that in the period that every 100,000 average population served by 2-15 units. There are 5 five provinces with $\mathrm{CHC}$ per 100,000 population ratio is under 3.0 are the provinces of Banten, West Java, East Java, Central Java, and Bali.

In terms of public health policy implementers, the ratio of health workers to 100,000 people nationwide are 195.88 and compared between provinces in Java and Bali, West Java turns ranks fourth from the bottom in the amount of 114.40 .

The problem is that mothers and public health officials do not have the knowledge about the prevention or treatment of common diseases of children. In West Java, one in three children under five suffer from fever (which may be caused by malaria, 
ARTIKEL

acute respiratory infections and others), and one in seven children under five suffer from diarrhea. Most deaths from these diseases can be prevented. However, in order to prevent these diseases, there are things to be fulfilled such as the necessary knowledge, the timely introduction, handling and behavior change mothers and health workers. For example, the Demographic Health Survey 2007 showed that only 61 percent of children under five with diarrhea were treated with oral rehydration therapy.

Steps toward improving the quality require additional resources to develop and motivate health workers. Health worker performance is determined both by the skill and motivation. To develop skills, it is not only required more training, it also needs facilitative supervision of case management, and for professionals, peer assessment, periodic monitoring and audit significant events or death is very important to note. Session feedback, monitoring and supervision continuously play an important role, not only in improving quality but also in motivating the team. West Java of Indonesia may consider providing incentives to health workers. These incentives can take the form of non-cash (increased duties, ownership, and recognition of the profession), money (additional performancebased component of the salary), or the institutional and team-based (measures such as accreditation systems and open competition).

However, all this was not enough. District medical officers are always lacking, especially, if it in remote, in the mountains, forests or coastal areas. To that end, health workers are still needed to be added. Here it is also important to always train people so that they can handle their own illness. This can be done with their intensive contacts either through traditional media such as gathering events in the villages, or other social media, whether it is Facebook, WhatsApp, Blackberry, or other.

\section{E. Conclusion}

Based on the results of the research and discussion the following are the conclusions:

1. The implementation of maternal and child health services in run by West Java Health Offices was not so massive, whereas by the existence of the 
program of Health Insurance there were many things should be presented to the public.

2. The implementation of public health policies have been done with the pattern of decentralization. This will weaken the power of human resources, for they are divided largely. The announcement about the public health services operated independently in their respective areas, with their respective media.

3. West Java Provincial Health Office did not fully socialized the new structure of health services with policy support in the form of general policy, implementation guidelines and instructions for the technical implementation of public health services, especially on maternal and child health, to the public. The lack of clear public policy and technical implementation guidelines has puzzled public health stakeholders, especially those who cooperate with public health services such as Health Insurance and the users.

4. The unity of the coordination and uniformity of information services, and a network of cooperation in public health institutions, in the Provincial Government of West Java have been performed well.

5. In implementing their obligations the implementers are highly motivated for the services of public health have become a major function in the duties and functions of the health department. However, the lack of health care workers who directly addressing maternal and child health were perceived by the public so well that this study recommend the convening of additional health workers in the community.

6. In order for the communication of the maternal and child health services can be implemented properly, there should be supported by a variety of media, including social media and even traditional media. 
ARTIKEL

\section{BIBLIOGRAPHY}

Anwar, R.K., Rusmana, A. and Rahman, M.T. (2018). The Politics Of Information On Traditional Medical Practices In Bandung Barat. MIMBAR, Vol. No 1st (June) 2018 pp. 158-165, 34(1), pp.158-165.

Arifanto, Alex. (2004). Reformasi Sistem Jaminan Sosial di Indonesia: Sebuah Analisis Atas Rancangan Undang- Undang Jaminan Sosial Nasional (RUU Jamsosnas). Jakarta: Lembaga Penelitian SMERU.

Azwar, Azrul. (1996). Pengantar Administrasi Kesehatan. Jakarta: Binarupa Aksara.

Buku Pegangan Sosialisasi Jaminan Kesehatan Nasional (JKN) dalam Sistem Jaminan Sosial Nasional. (2013). Kementerian Kesehatan Republik Indonesia.

Creswell, John. W. (2012). Research Design Qualitative \& Quantitative Approaches. $9^{\text {th }}$ edition.Thousand Oaks, CA: Sage Publication.

Denzin, Norman K and Yvonna S. Lincoln. (1994). Handbook of Qualitative Research.Thousand Oaks, CA: Sage Publications.

Dever, G.E. Alan. (1984). Epidemiology in Health Services Management. Madrid: Aspen.

Dimock, Marshall Edward and Dimock, G.G.O. (1953). Public Administration. Rinehart.

Gordon., I., J. Lewis. (1986). Perspectives on Policy Analysis. In Public Administration Bulletin, Vol. 25.

Howlett, Michael dan M. Ramesh. (1995). Studying Public Policy: Policy Cycles and Policy Subsystem.New York: Oxford University Press.

http://economy.okezone.com/read/2013/12/31/320/919653/sby-resmikanprogram-bpjs-kesehatan.

http://www.kompasiana.com/coretanku/bpjs-kesehatan-mempersulit-prosespendaftaran-online 54f37bfa745513a12b6c770f.

http://www.nolduanews.com/2016/09/peserta-bpjs-kesehatan-ciamiskeluhkan.html.

Indonesia, R., \& Nomor, U. U. (23). Tahun 2014 Tentang Pemerintahan daerah. Tambahan Lembaran Negara Republik. Indonesia Nomor, 5587.

Jones, Charles O. (1984). An Introduction To The Study Of Public Policy, Monterey, California; Brooks/Cole Publishing Company.

Kesehatan, I. D. (2008). Peraturan Menteri Kesehatan Republik Indonesia Nomor: 741/MENKES/PER/VII/2008 tentang Standar pelayanan minimal bidang kesehatan di kabupaten/kota-[PERATURAN].

Locke, L.; Silverman, S.; Spirduso, W.W. (1987). Reading and Understanding Research. Thousand Oaks, CA: Sage Publications.

Marshall, Catherine and Rossman, Gretchen B. (1989). Designing Qualitative Research. Newbury Park, CA: Sage Publications. 
Miles, M.B. and Huberman, A.M. (1994). Qualitative Data Analysis: An Expanded Sourcebook. $2^{\text {nd }}$ edition.Thousand Oaks, CA: Sage Publications.

Mulyadi, Mohammad. (2014). Info Singkat: Sosialisasi Ketentuan Jaminan Sosial 2014. Jakarta: P3DI Setjen DPR RI.

Presiden, R. I. (2009). Undang-Undang Republik Indonesia No. 36 Tahun 2009 Tentang Kesehatan. Presiden Republik. Indonesia, Jakarta.

Pressman, J. and A. Wildavsky. (1973). Implementation, Berkeley, California: University of California Press.

Ripley, Randall and Franklin, Grace. (1980). Congress, the Bureaucracy and Public Policy. $2^{\text {nd }}$ ed. Homewood, Ill: The Dorsey Press.

Sugyati, C., (2018). Analisis atas kebijakan pemerintah tentang BPJS dan JKN melalui UU 36 tahun 2009 Tentang Kesehatan. TEMALI: Jurnal Pembangunan Sosial, 1(1), pp.73-85.

Sugyati, C., Sjoraida, D. F., \& Anwar, R. K. (2017). Pemahaman Kebijakan Kesehatan Masyarakat Bidang Ibu dan Anak Pada Pelaksana Lapangan di Jawa Barat. Jurnal Ilmu Pemerintahan: Kajian Ilmu Pemerintahan dan Politik Daerah, 2(1), 52-60.

Udoji, Chief J.O. (1981). The African Public Servant as a Public Maker, Public Policy in Africa, Africa Association for Public Administration.

www.bpjs.info. (2013). "Sosialisasi Jaminan Kesehatan Nasional Masih Minim",http://www.bpjs.info/beritabpjs/Sosialis asi_Jamina n kesehatan Nasional Masih Minim-5194, accessed Januari 21, 2013. 